Article

\title{
Feeding Specialization of Honey Badgers in the Sahara Desert: A Trial of Life in a Hard Environment
}

\author{
Jose María Gil-Sánchez ${ }^{1,2, *}$, F. Javier Herrera-Sánchez ${ }^{1}$, Javier Rodríguez-Siles ${ }^{1}$, \\ Juan Manuel Sáez ${ }^{1}$, Miguel Ángel Díaz-Portero ${ }^{1}$, Ángel Arredondo ${ }^{1}$, Begoña Álvarez ${ }^{1}$, \\ Inmaculada Cancio ${ }^{1}$, Jesús de Lucas ${ }^{1}$, Salvador Castillo ${ }^{1}$, Emil McCain ${ }^{1}$, Joaquín Pérez ${ }^{1}$, \\ Gerardo Valenzuela ${ }^{1}$, Jaime Martínez Valderrama ${ }^{1}$, Jesús Bautista ${ }^{1}$, Carlos Sarabia ${ }^{3}{ }^{(0)}$, \\ Jennifer Leonard ${ }^{3}$, Mariola Sánchez-Cerdá ${ }^{3}$, Emilio Virgós ${ }^{4}$ and Abdeljebbar Qninba ${ }^{5}$
}

1 Harmusch, Association for the Study and Conservation of Wildlife. C/ San Antón 15, 1 . E 13580 Almodóvar del Campo, Ciudad Real, Spain; capyjavi@hotmail.com (F.J.H.-S.); rioyeguas@gmail.com (J.R.-S.); saezjuanma@hotmail.com (J.M.S.); madportero@gmail.com (M.Á.D.-P.); angel.arredondo@yahoo.es (Á.A.); begonalvarez@gmail.com (B.Á.); mijiketa@hotmail.com (I.C.); jdlucas@jccm.es (J.d.L.);

salvador@deportesnatura.com (S.C.); emilmccain@gmail.com (E.M.); saurojoaco@hotmail.com (J.P.); gerarvase@gmail.com (G.V.); jaimonides@gmail.com (J.M.V.); jfasciatus@yahoo.es (J.B.)

2 Departamento de Zoología, Universidad de Granada, Avda. de Fuente Nueva, s/n, 18071 Granada, Spain

3 Conservation and Evolutionary Genetics Group, Estación Biológica de Doñana (EBD-CSIC), Avda. Americo Vespucio 26, 41092 Seville, Spain; cdomsar@ebd.csic.es (C.S.); jleonard@ebd.csic.es (J.L.); siyofuerapajaro@gmail.com (M.S.-C.)

4 Escet, Departamento de Biología y Geología, Universidad Rey Juan Carlos, C/Tulipán, s/n, E 28933 Madrid, Spain; emilio.virgos@urjc.es

5 Mohammed V University in Rabat, Institut scientifique, Laboratoire de Géo-Biodiversité et Patrimoine Naturel, Centre de Recherche GEOPAC, Av. Ibn Battota, B.P. 703, 10090, Agdal, Rabat, Morocco; qninba_abdel59@yahoo.fr

* Correspondence: jmgilsanchez@yahoo.es

Received: 19 December 2019; Accepted: 1 February 2020; Published: 2 February 2020

check for updates

\begin{abstract}
The honey badger (Mellivora capensis) is a medium-sized carnivore distributed throughout Africa to the Arabian Peninsula, Iran, Turkmenistan, and India. However, available information on its ecology is very scarce. We studied its feeding ecology in the remote north-western Sahara Desert, based on the contents of 125 fecal samples collected during large scale surveys. Samples were confirmed to belong to honey badgers by camera trapping and genetic analyses. Barely 18 prey species were detected. The diet primarily consisted of spiny-tailed lizards Uromastyx nigriventris and $U$. dispar (72\% of volume in scats). Secondary prey items were arthropods $(14 \%)$, small mammals $(8 \%)$, other reptiles $(4 \%)$, and eggs $(0.8 \%)$. Some small geographic and temporal differences were related to the consumption of beetle larvae and rodents as alternative prey. Camera trapping and distance sampling surveys showed that diel activities did not overlap between honey badgers and spiny-tailed lizards, suggesting that badgers primarily dig lizards out of their burrows when inactive. Consumption of spiny lizards by other sympatric meso-carnivores was $<6.1 \%$ of occurrence (223 analyzed scats); the honey badger behaved as a trophic specialist in the Sahara, probably thanks to exclusive anatomical adaptations for digging. We discuss the role of this circumstance minimizing the exploitative competition, which could allow the survival of this large mustelid in this low productive and highly competitive environment.
\end{abstract}

Keywords: arid environments; exploitative competence; specialist; feeding ecology; Mellivora capensis; Sahara; Uromastyx genus 


\section{Introduction}

The largest desert in the World, the Sahara (9.2 million $\mathrm{km}^{2}$; almost the area of Europe, $10.2 \mathrm{~km}^{2}$ ), has a surprising rich community of mammalian carnivores with up to 14 species after excluding some recently extinct taxa (lion Panthera leo and wild dog Lycaon pictus [1,2]). However, basic information on the biology of many species in the Sahara remains mostly unknown, primarily due to both severe logistic limitations and political conflicts, which imply the lack of security for researchers in several areas $[3,4]$. One of these carnivores is the honey badger (Mellivora capensis), a large mustelid widespread through most of Africa to the Arabian Peninsula, Iran, Turkmenistan, and the India sub-continent, including the western Sahara Desert, from Mauritania and Mali to southern Morocco and north-western Algeria [1,5]. However, detailed studies of honey badger ecology are limited to southern Africa [6,7], and only opportunistic observations scattered in the Sahara Desert are available [5,8,9] Any aspect of its biology in the extreme habitats of the Sahara (as well as other areas) remain poorly understood. On the other hand, the North-western Sahara range of the honey badger is located in the Northern distribution range of the species in Africa, which represents biogeographic interest where severe ecological limitations are predictable. Moreover, recent species distribution models suggest that the honey badgers of NW Sahara could be currently isolated from the rest of African populations [10].

Honey badgers capture most of their prey by digging with powerful and broad front feet and long claws [5], preying mostly on small burrowing vertebrates and insects and, secondarily, roots, berries, and fruits [1,5-9]. On the other hand, the richness (or diversity) of the Saharan carnivore community in the very low productive Saharan eco-region $[1,2,11]$ implies a highly competitive scenario, where strong niche partitioning is expected following the competitive exclusion principle [12]. Here, we present the first detailed information on the feeding ecology of the honey badger in the Sahara Desert, based on the analysis of fecal samples collected during large scale surveys carried out in remote areas of the Sahara. We hypothesized honey badgers to lower exploitative competition by preying primarily upon small burrowing vertebrates and insects only marginally used by other sympatric carnivore species. We assessed the diel activity of badgers and other mesocarnivores' diets to test for this hypothesis. This is an interesting scenario to study the adaptations and or conditions that allow the survival of isolated populations living in marginal habitats. In fact, key local adaptations in the feeding ecology of marginal and or isolated populations can lead to allopatric speciation, being an important driver of evolution [13]. Further, from a conservation point of view, as the honey badger is a near-threatened taxa in the Maghreb countries [14], this information contributes to correctly designed conservation strategies. This is a key goal to face the severe crisis that currently affects the rich wildlife of the Sahara, where much more scientific attention is required $[2,3]$.

\section{Materials and Methods}

\subsection{Study Area}

The study area was in the Atlantic Sahara (Morocco), a low-latitude subtropical desert with arid hot climate (after Köppen-Geiger classification, [15], where the mean temperature ranges from 22.7 ${ }^{\circ} \mathrm{C}$ in the west (closer to the Atlantic Ocean) to $23.2{ }^{\circ} \mathrm{C}$ in the eastern inland areas, and total annual precipitation ranges from 138 to $59 \mathrm{~mm}$, respectively (climate stations at Smara: $26^{\circ} 46^{\prime} \mathrm{N}, 11^{\circ} 31^{\prime} \mathrm{W}$, $460 \mathrm{~m}$ and Tindouf: $\left.27^{\circ} 40^{\prime} \mathrm{N}, 8^{\circ} 7^{\prime} \mathrm{W}, 401 \mathrm{~m}\right)$. Three areas were surveyed for the present study. The first one was located between the lower Draa River and the upper basin of the Sequiat Al Hamra, (ca km²; altitude ranges $290-770 \mathrm{~m}$ a.s.l.; Figure 1). It is a hilly and rocky terrain with intercalated hamadas (elevated plains) and regs (gravels/stony plains). A complex network of ancient dry rivers crosses the entire region, some of them collecting seasonal waters and even the main basins, while the main rivers, the Draa and the Chebeica, hold some permanent water pools, called gueltas. The vegetation is scarce except in the dry rivers basins, where large open savannah-like forests of horn trees (Acacia raddiana) persist, somewhere with Egyptian balsam (Balanites aegyptiaca) and Sodom apple (Calotropis procera) and Rhus tripartita bushes, while tamarisk (Tamarix africana) grows near the gueltas. The endemic tree 
of Morocco, the argan (Argania spinosa), reaches its southernmost limit here as scattered individuals sheltered in the valleys. The second area comprises the Oued Khat basin (Figure 1), a fossil river valley dominated by reg plains with rocky hills and steps at the borders (ca $1200 \mathrm{~km}^{2}, 110-220 \mathrm{~m}$ a.s.1.). The vegetation is formed by scattered horn trees and camephites as Nucularia perrini. The third area includes the Negjyr Mounts, the Aouserd Mounts and the Oued Jenna (Figure 1), which conform small island-mounts $\left(6-80 \mathrm{~km}^{2}\right)$ and an ancient dry river located in the huge Atlantic Saharan plain (ca $5100 \mathrm{~km}^{2}$, 180-350 $\mathrm{m}$ a.s.l.). Climate and vegetation are similar to the Oued Khat area, but the grass Panicum turgidum is more widespread.

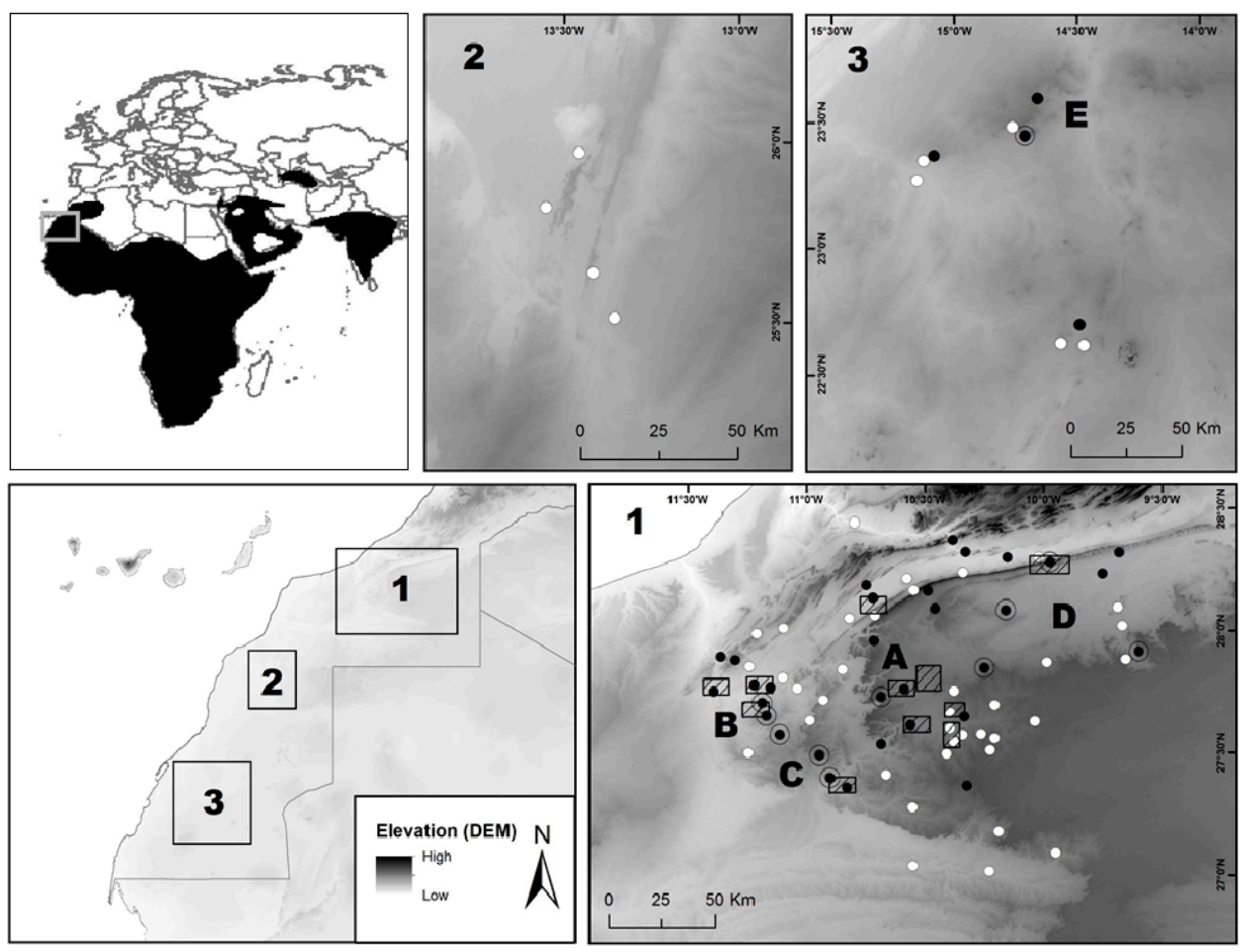

Figure 1. Study areas in the Atlantic Sahara (from 2013 ESRI, i-cube, GeoEye), honey badger global range [14] and distribution of the walking survey plots: Black points are sites where honey badgers were detected (feces, footprints, camera trap records and sightings) and white points are negative surveys; encircled black points show where the honey badger feces were collected: A) Red Aydar, B) Black Aydar N, C) Black Aydar SE, D) Tigsert Basin, E) Negjyr. Rectangles show the camera trapping sites.

Currently, the carnivore mammals community of the Atlantic Sahara is formed by 12 species belonging to 6 families [11]: 4 canids (African golden wolf Canis anthus, red fox Vulpes vulpes, Ruppell's fox V. rueppellii, fenec fox V. zerda), 3 felids (caracal Caracal caracal, African wildcat Felis lybica, sand cat F. margarita), 2 mustelids (honey badger and Saharan striped weasel Poecilistis libyca), 1 viverrid (common genet Genetta genetta), 1 herspestid (Egyptian mongoose Herpestes ichneumon) and 1 hyenid (striped hyaena Hyanea hyanea). We failed to detect cheetahs (Acinonix jubatus), which probably became extinct at the end of the 20th century [11].

\subsection{Field Surveys}

We monitored the carnivore community of the 3 study areas during 22 expeditions of 1 to 2 weeks each (from April 2011 to April 2019). A total of 68, 4, and 9 plots were, respectively, sampled within the 3 areas (Figure 1), searching for carnivore's signs along 1-4 transects (mean length: $12.08 \pm 0.72 \mathrm{~km}$ per walking survey, for a total of $2.490 \mathrm{~km}$ accumulated effort). During each walking survey, 2 to 9 observers searched for carnivore feces, tracks, and den sites [16,17], following a stratified sampling strategy within the available habitats in each sampling point. 


\subsection{Feces Identification}

The honey badger feces can be confused with those feces of similarly sized sympatric carnivore species (African golden wolf, red fox, and African wildcat). In the field, scats were preliminarily assigned to the honey badger whenever other signs of presence, such as tracks and hairs, were found. Then, we employed camera trapping at the first found den (Red Aydar, April 2014, Figure 1) for positive species identification [18]. Two passive infra-red triggered cameras were set relatively close $(10 \mathrm{~m})$ and just in front one of the den entrances for 5 days with bee honey as a lure. Two males honey badgers were photographed on 2 different days (Figure 2) and no other carnivore species were detected. This would confirm that the 38 scats (see Table 1 ) found next to the den probably belonged to honey badgers

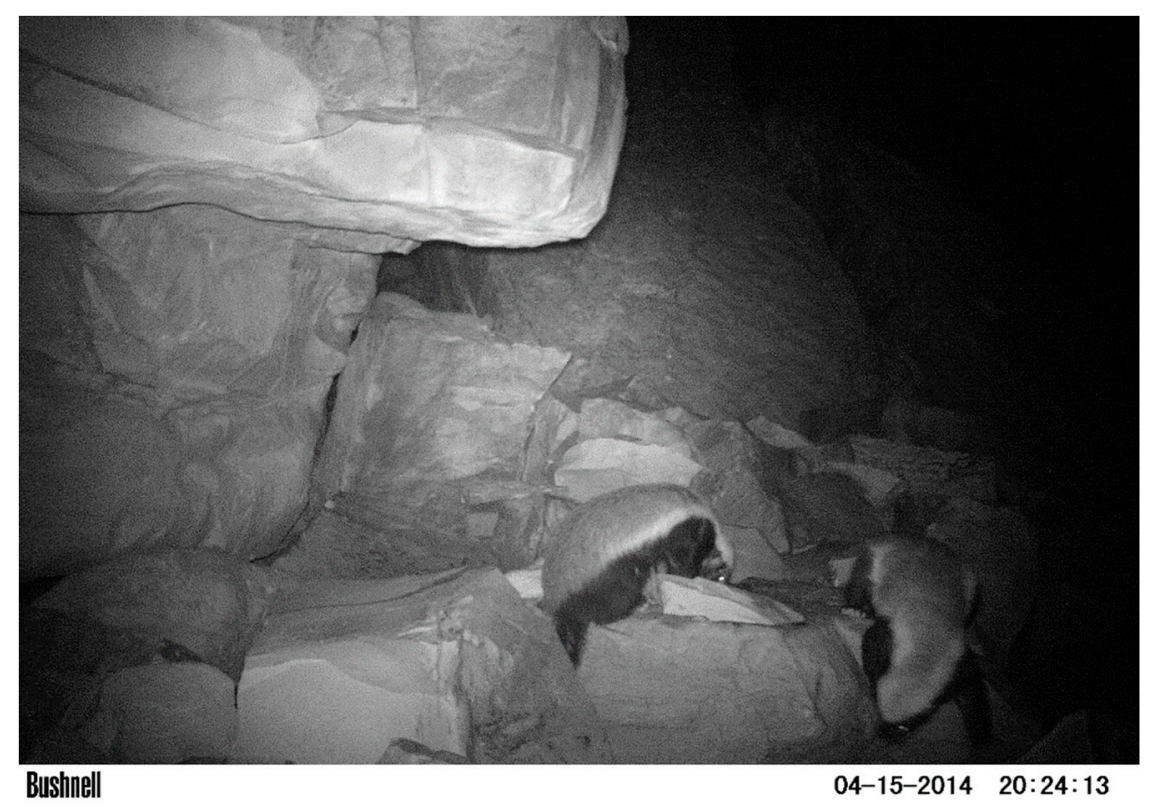

Figure 2. A picture of the first honey badgers taken by a camera-trap in our study, showing the typical micro-habitat where this species shelters in the study area. The entrance of the den (not visible in the picture) was located just to the left of the left-most individual.

We used laboratory confirmation by DNA isolation and identification. First, we extracted the DNA of 223 carnivore feces collected everywhere during the walking surveys, which were identified at species level. Second, we extracted the DNA of a sub-sample of 28 out of 119 feces found around dens and in latrines, including 10 samples of the camera-surveyed den previously described; these 119 samples were in situ identified as honey badger scats, following shape, size, and location criteria, once we learnt from the scats that could be identified by camera trapping. All samples were handled in an isolated, dedicated low-quality DNA laboratory, which was cleaned with bleach and irradiated between each reaction. Mitochondrial DNA was extracted from the feces with the QIAamp DNA Stool Kit (Qiagen, Hilden, Germany), using phenol-chloroform-isoamyl alcohol (PCI; [19]), or by silica [20], using a negative extraction control for every 5 samples.

Two PCRs targeting a $280 \mathrm{bp}$ fragment of the cyt b were carried out per extract and negative with primers CCB53 5'-CCTATTCCTAGCCATACACTACA [21] and uCB54 5'-AAGGATATTTGGCCTCATGG [22]. PCR negatives were included in each batch. Each $12 \mu \mathrm{L}$ reaction contained $1 \mathrm{U}$ GoldTaq polymerase ${ }^{\circledR}, 1 \mathrm{X}$ GoldTaq Buffer ${ }^{\circledR}, 2.5 \mathrm{mM} \mathrm{MgCl} 2,1 \mathrm{mM} \mathrm{dNTP}$, $0.4 \mathrm{mM}$ BSA, $0.5 \mu \mathrm{M}$ each primer, and $3 \mu \mathrm{L}$ of DNA extract. Cycling was carried out in a BioRad T100 thermocycler, with initial denaturation at $95^{\circ} \mathrm{C}$ for $8^{\prime \prime}$; we ran 45 cycles of $95^{\circ} \mathrm{C}$ for $30^{\prime \prime}, 55^{\circ} \mathrm{C}$ for $30^{\prime \prime}, 72^{\circ} \mathrm{C}$ for $60^{\prime \prime}$, with a final extension at $72{ }^{\circ} \mathrm{C}$ for $7^{\prime}$. Products were checked in a $2 \%$ agarose gel and visualized on a Gel Doc ${ }^{\mathrm{TM}}$ EZ Gel transiluminator (Bio Rad, Hercules, CA, USA). PCR products 
were purified using Sera Mag SPRI beads [23] and checked by agarose gel electrophoresis and Sanger sequenced (Macrogen, Madrid, Spain).

We trimmed primer and low-quality base pairs from the sequences and BLASTed them against the GenBank database using the blastn algorithm [24] implemented in Geneious v11.0.5 [25]. Sequence identity was approximated by similarity in the whole database and then confirmed by phylogenetic analyses. Reference sequences from all carnivores present in the region were obtained from GenBank and a neighbor-joining phylogeny was constructed in Geneious with default parameters. Twenty-three of the selected 28 feces were successfully amplified and sequenced, 14 in duplicate. All were positively identified as honey badger through similarity and phylogenetic analyses. Therefore, the identification success ratio of feces identified in situ (samples found around dens and latrines) was $100 \%$. Of the 223 feces collected during the carnivore surveys, 6 belonged to the honey badger. In total, we obtained 125 confirmed feces.

\subsection{Faecal Analysis and Diet Composition}

The scats, previously dry-preserved with silica-gel, were broken up and the prey remains were identified to species, where possible, based on macroscopic characteristics of bones, hairs, reptile scales, and invertebrates pieces compared with the reference personal material of collection, bibliography (rodent teeth: [11]) or were consulted to specialists (Coleoptera Order). The percentage of the volume of each identified prey per scat was estimated visually [26,27]. The composition of the diet was expressed as a percentage of volume $(\% \mathrm{~V}=$ estimated volume of each prey type/total estimated volume $x$ 100). In order to study regional variations in diet, the samples were separated into 5 areas (Figure 1). Seasonal and/or inter-annual variations could be studied only for one area (Red Aydar, see Figure 1) due to sampling size limitations; the samples obtained in this area during 2 visits were considered separately (see Table 1). Food items were grouped into 5 categories: Spiny-tailed lizard, other reptiles, small mammals, eggs and arthropods. Kruskal-Wallis's tests were used to detect overall differences in the diet for each one of the 5 categories, whereas Mann-Whitney's $U$ tests were used to detect differences for each category between pairwise areas/seasons. The sample of Negjyr ( $<10$ scats, Table 1) was excluded from U tests.

Table 1. The occurrence of the prey species in the honey badger feces (feces in which each item was found).

\begin{tabular}{|c|c|c|c|c|c|c|}
\hline Food Item & $\begin{array}{l}\text { Red Aydar } \\
\text { Apr.2014 }\end{array}$ & $\begin{array}{l}\text { Red Aydar } \\
\text { Dec. } 2016\end{array}$ & $\begin{array}{c}\text { Black Aydar SE } \\
\text { Apr.2014 \& Dec. } 2016\end{array}$ & $\begin{array}{l}\text { Black Aydar } \\
\text { N Dec } 2016\end{array}$ & $\begin{array}{c}\text { Tigsert Basin } \\
\text { 2012-2019 }\end{array}$ & $\begin{array}{c}\text { Negjyr } \\
\text { Jan. } 2015\end{array}$ \\
\hline Uromastyx nigriventris & 30 & 9 & 18 & 15 & 10 & 0 \\
\hline Agama sp./Trapelus sp. & 1 & 0 & 2 & 1 & 1 & 0 \\
\hline Snake n.i. & 1 & 1 & 1 & 0 & 0 & 0 \\
\hline Lepus sp. & 1 & 0 & 0 & 0 & 0 & 0 \\
\hline Psammomys obesus & 0 & 2 & 0 & 4 & 0 & 0 \\
\hline Acomys cahirinus & 0 & 1 & 0 & 0 & 0 & 0 \\
\hline Rodentia n.i. & 0 & 1 & 1 & 1 & 0 & 0 \\
\hline Alectoris barbara eggs & 1 & 0 & 0 & 0 & 0 & 0 \\
\hline Reptile egs & 1 & 0 & 2 & 0 & 0 & 0 \\
\hline Scolopendra & 1 & 0 & 0 & 0 & 0 & 0 \\
\hline Artropod n.i. & 1 & 0 & 0 & 0 & 0 & 0 \\
\hline Lepidoptera pupae & 0 & 0 & 1 & 0 & 0 & 0 \\
\hline Mud & 1 & 0 & 0 & 0 & 0 & 0 \\
\hline $\mathrm{N}$ & 38 scats & 25 scats & 23 scats & 22 scats & 11 scats & 6 scats \\
\hline
\end{tabular}




\subsection{Predator-Prey Relationships: Abundance and Diel Activity of the Staple prey}

In order to know how abundant the staple prey was, data on the density of spiny-tailed lizard Uromastyx nigriventris was estimated by distance sampling [28] by counting from vehicles. Samplings $(N=4)$ were carried out in late summer (25-26 September 2018), when lizards were active ([29]; this study) and thus should be recorded effectively. Transects were stratified by the 3 major habitats of the study area: Gravels/sandy reg (one transect of $32.49 \mathrm{~km}$ ), stony reg (two transect of 27.01 and $20.0 \mathrm{~km}$ ) and rocky hills (one transect of $8.38 \mathrm{~km}$ ); given to the great homogeneity within these habitats, we assumed that our car surveys $(87.88 \mathrm{~km}$ in total) were representative of the entire study area. During the surveys, one car was slowly driven $(<10 \mathrm{~km} / \mathrm{h}$ ) and two observers (not the driver) counted the individuals, one on each side of the route, taking the perpendicular distance (in $\mathrm{m}$ ) to the survey line of each observation by rangefinder. The program DISTANCE 6.0 [30] was used to calculate density $(D)$. The detection function was half-normal, since: (1) Data set allowed for neither uniform nor hazard-rate functions, (2) the half-normal function resulted in lower AIC values than the negative exponential function.

We explored whether the diel activity of the honey badger was shaped by the activity of its staple prey. U. nigriventris is a strictly diurnal species [29] that in the study area can be observed out of its burrows from $1 \mathrm{~h}$ after sunrise to $1 \mathrm{~h}$ before sunset (this study). Honey badger diel activity was estimated by camera trapping. Eleven surveys (Figure 1) with 3 to 24 cameras each (passive infrared triggered) were carried our since 2012 to 2019. Cameras were deployed for periods lasting five days to one year, totalling camera days for 159 effective cameras (some devices were stolen). We used digital passive infrared-triggered devices, baited at 3-6- $m$ with Iberian lynx (Lynx pardinus) urine [31]. The date and time of each photograph were recorded. The diel activity pattern of honey badgers was assessed following Monterroso et al. [32], using Kernel density estimates (see details in [33]). All captures were separated $>1$ day, hence, they can be assumed as independent [18]. Very few pictures of lizards were obtained, insufficient for any activity analysis. We carried out the diel calculation by $\mathrm{R}$ [34], following the code provided by Ridout and Linkie [33].

\subsection{Role of Staple Prey of Honey Badger in the Diet of Other Sympatric Carnivores}

We studied the consumption of the staple prey of honey badgers by other carnivores living within the study area, with the aim of testing our hypothesis of niche segregation. The 223 identified carnivore feces were analyzed in detail to detect remains of the spiny-tailed lizard. We analyzed 80 samples belonging to African golden wolf, 37 to the red fox, 92 to the African wildcat, 7 of the Ruppell's fox, 3 of the fenec fox, 2 of the genet and 2 of the striped hyena.

\section{Results}

We were able to obtain 119 feces from the first area and 6 from the third area, failing to find any sample in the second area (see Figure 1). Within the first area, two occupied honey badger dens were discovered in April 2014, which held several scats around; in December 2016, we found three latrines containing honey badger-like feces. All these samples were collected and confirmed to belong to the target species, being resampled up to four times in following expeditions in order to obtain temporal variability in the sample.

The diet included 18 identified species (Table 1). Overall, there were only three key prey items: Spiny-tailed lizards (72.0 of average $\% \mathrm{~V})$, arthropods, mainly larvae of one unidentified species of Melolonthidae (Coleoptera) $(14.4 \%$ of average V) and rodents ( 8.5 of average $\% \mathrm{~V})$. However, the importance of arthropods and rodents was local, whereas spiny-tailed lizards showed a key role in all the studied areas (Figure 3). No plant material was found in the samples. Statistical differences were found in the complete sample for the spiny-tailed lizard $\left(\mathrm{K}-\mathrm{W} \mathrm{Ch} i^{2}=15.17\right.$, f.d. $\left.=5, P=0.01\right)$, small mammals (K-W Chi ${ }^{2}=29.49$, f.d. $\left.=5, P<0.0001\right)$ and arthropods $\left(\mathrm{K}-\mathrm{W} \mathrm{Chi}{ }^{2}=53.90, f . d .=5\right.$, $P<0.0001)$. Some differences were detected by the pairwise comparisons, which were related to the 
consumption patterns of spiny-tailed lizards and Melolonthidae larvae in Red Aydar and rodents in North Black Aydar (Table 2).

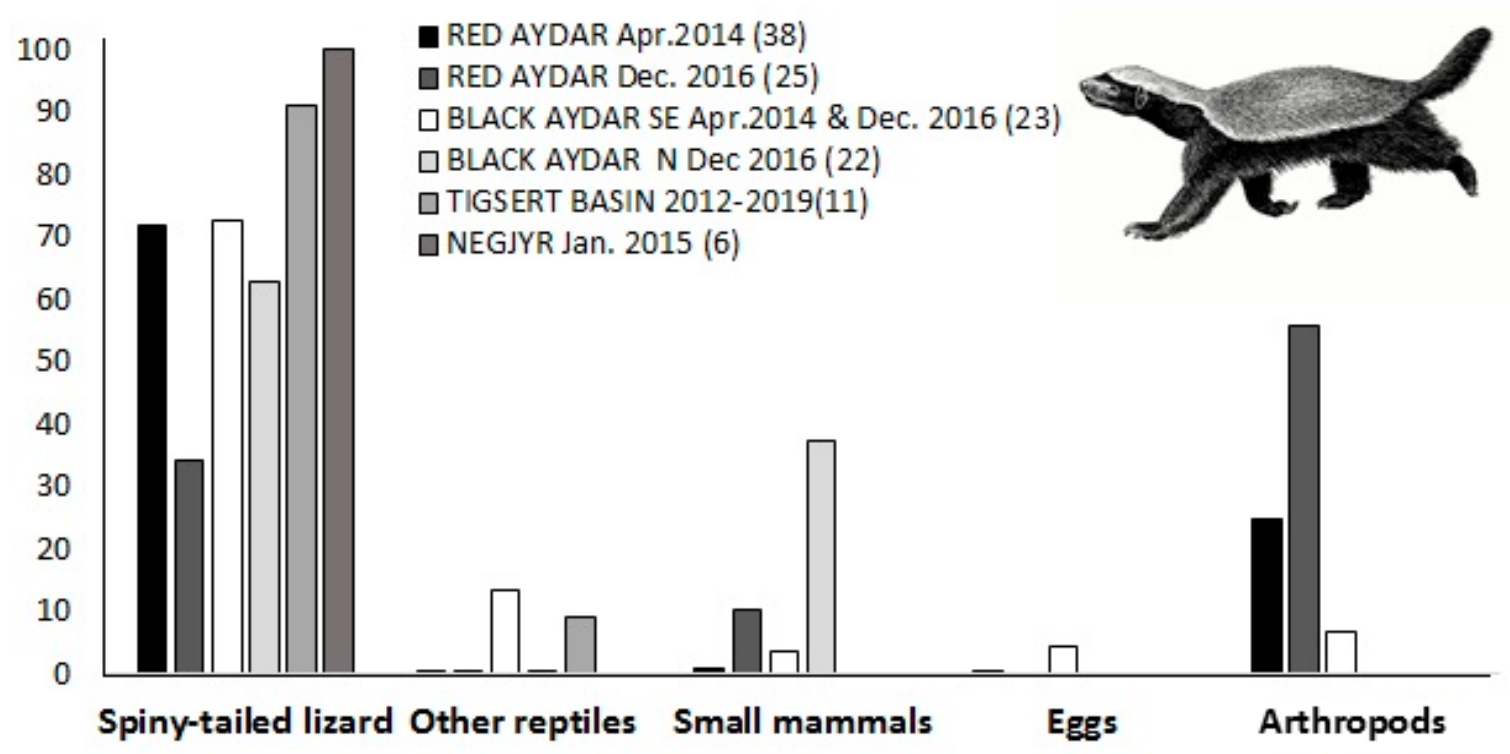

Figure 3. Diet of the honey badger in the Atlantic Sahara expressed as a percentage of volume in the scats. In ( ) number of feces.

Table 2. Results of Mann-Whitney's pairwise tests ( $P$ values corrected by the Holm-Bonferroni adjustment) between areas/seasons.

\begin{tabular}{|c|c|c|c|c|}
\hline \multicolumn{5}{|c|}{ Spiny-Tailed Lizard } \\
\hline & Red Aydar Apr. 2016 & Red Aydar Dec. 2014 & Black Aydar SE & Tigsert Basin \\
\hline Red Aydar Apr. 2014 & - & & & \\
\hline Red Aydar Dec. 2016 & n.s. & - & & \\
\hline Black Aydar SE & n.s. & 0.0001 & - & \\
\hline Black Aydar N & n.s. & n.s. & n.s & - \\
\hline Tigsert basin & 0.005 & 0.001 & n.s. & n.s. \\
\hline \multicolumn{5}{|c|}{ Melolonthidae } \\
\hline Red Aydar Apr. 2014 & - & & & \\
\hline Red Aydar Dec. 2014 & n.s. & - & & \\
\hline Black Aydar SE & 0.001 & 0.001 & - & \\
\hline Black Aydar N & 0.0001 & 0.0001 & n.s & - \\
\hline Tigsert basin & 0.006 & 0.009 & n.s. & n.s \\
\hline \multicolumn{5}{|c|}{ Small Mammals } \\
\hline Red Aydar Apr. 2014 & - & & & \\
\hline Red Aydar Dec. 2016 & n.s. & - & & \\
\hline Black Aydar SE & n.s. & n.s. & - & \\
\hline Black Aydar N & 0.0001 & n.s. & 0.001 & - \\
\hline Tigsert basin & n.s. & n.s. & n.s. & n.s. \\
\hline
\end{tabular}

The estimated density of the spiny-lizard was 1.89 individuals $/ \mathrm{km}^{2}(\mathrm{SE}=1.36)$, excluding the gravel/sandy regs, since the presence was anecdotic (only one record). The number of records were insufficient to estimate the density within each habitat, but the relative abundance was highly variable: 0.03 individuals $/ \mathrm{km}$ in gravel $/ \mathrm{sandy}$ regs, $0.14-0.20$ individuals $/ \mathrm{km}$ in stony regs and 1.55 individuals $/ \mathrm{km}$ in rocky hills. The honey badger was active mostly at night (23 out of 27 remote camera captures, $85.2 \%$; see Figure 4 ).

We detected spiny-tailed lizard remains in 5 feces of African golden wolf (6.1\%), 4 of African wildcat $(4.3 \%)$ and in 1 of the red fox $(2.7 \%)$. 


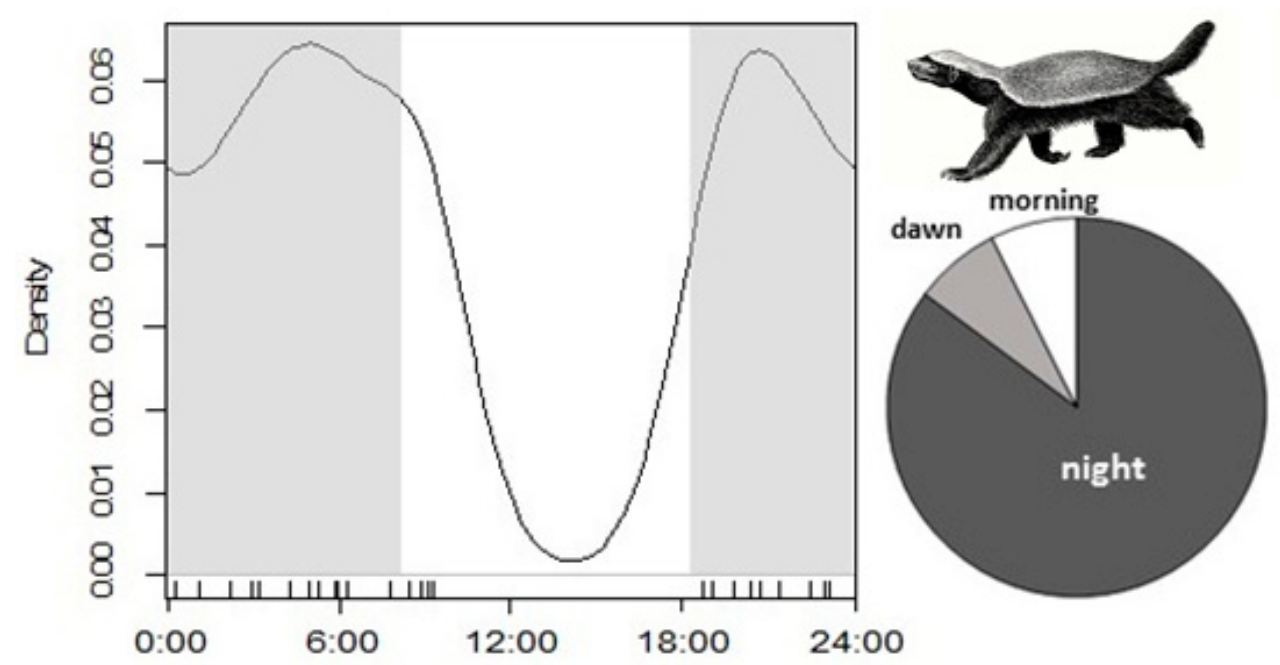

Figure 4. Activity patterns of the honey badger in the Atlantic Sahara. Darkness hours are indicated by the shaded area. Short vertical lines above the $x$-axis represent the 27 independent records. The pie chart represents these 27 records.

\section{Discussion}

Our hypothesis that honey badgers prey primarily upon small burrowing vertebrates and insects was fulfilled, showing a particular trophic specialization in the study area. The observed diet was much less diverse than that described in the most detailed honey badger study, which was conducted in Kgalagadi Transfrontier Park (South Africa and Botswana); Kgalagadi is a semi-arid southern African savannah (200-250 mm annual rainfall), where at least 59 species were consumed, with gerbils, geckos, and bee larvae the most frequently consumed items, whereas snakes and springhares were the most important in terms of biomass [7]. Another earlier study carried out in the same area showed that honey badgers ate mostly rodents, lizards, and scorpions [6]. The lesser diverse diet we observed in the north-western Sahara was expected since the Kgalagadi is a more productive environment than the Atlantic Sahara. Anyway, potential prey richness within our study area seems to be somewhat high: We have documented 9 snake species, 14 geckos and lizards, 2 hares, 5 large rodents, 8 small rodents (see also references [35] and [11]), and scorpions are really abundant. Although it is clear that availability estimations of potential prey are necessary for a wider discussion on food selection patterns, our data suggest that the honey badger could behave in the Sahara like a specialist, thus as the European badger Meles meles and earthworms in NW Europe [36]. Honey badgers were focused on the spiny-tailed lizard, which could be actively searched in the burrows even during its inactivity season (that lasts 5-6 months, from November to April, obs. of authors) or during its nocturnal resting period. The diel activity of the predator and prey do not overlap, but badgers probably find it easier to catch lizards in their burrows when inactive. The spiny-tailed lizard is a prey species that bears most of the characteristics to become a largely profitable food, as optimal foraging theory predicts [37]: It is locally abundant (in the rocky areas), with an apparent optimal size/weight for honey badgers (up to $0.6 \mathrm{~kg}$ [38]) and is probably easy for badgers to dig them out from their burrows, a local behavior previously described by Valverde [8]. Actually, it is well known that honey badgers capture most of their prey by digging [5].

Some plasticity in the honey badger diet may be suggested, probably related to changes in the availability of the Melolonthidae larvae and rodents, likely attributed to a short-term foraging response, as has been observed in other badger species (e.g., Meles meles and earthworms or rabbits, $[39,40]$ ). Spiny-tailed lizards are long-living reptiles well adapted to the extreme conditions of the Sahara Desert [41], therefore, it is not expected to suffer great temporal variations or short-term numerical responses like rodents or insects. 
The name "honey badger" was given due to the famous taste of this mustelid for bee honey [5]. The observed absence of bee remains in the collected samples might be due to low local availability, as no bee nests were found during the field walking surveys. However, honey badger attack hives in some areas of the near Anti-Atlas range of Morocco, generating a conflict with beekeepers that generate illegal lethal control [42]. Watermelons (Citrullus lanatus) play some marginal role in the diet of the honey badger in the Kalahari Desert [7]. Similar watermelons (C. colocynthis) are abundant in our study area, however, it was not found in the scats and we failed to detect tracks around several plants. The fruits of the Egyptian balsam were cited as consumed by the species in the Airr, Sahara of Niger [9], but were not detected in the diet in our study.

Although we recognize that further studies are necessary to assess the role of intra-guild competition in the carnivore community of the Atlantic Sahara, our results support the niche partitioning hypothesis. Carnivore species can coexist within a community by lowering interspecific competition [43]. Separation of trophic niche can be an efficient way to achieve coexistence (e.g., [44,45]. In our community, this coexistence was favored by honey badger specialization on the spiny-tailed lizard. The spiny-tailed lizard is difficult to capture by other carnivores than honey badgers due to: (1) This reptile usually burrows their dens in hard soils (obs. of authors) and (2) all carnivore species are primarily nocturnal here (data from our camera trapping survey). Thus, an optimal prey in terms of biomass remains available almost entirely for honey badgers within the carnivore mammal's community, which probably plays a key-role for the survival of the northern-most populations of Africa.

Our study highlighted some interesting adaptations of this large mustelid to the arid scenario of the Sahara Desert that deserves more in-depth studies. For further research on honey badger distribution and ecology within this remote region where rocky soils prevent the finding of tracks, we recommend searching for scats at den sites similar to those described, all located at relatively predictable rocky slopes.

Author Contributions: Conceptualization, J.M.G.-S., and F.J.H.-S.; methodology, J.M.G.-S., F.J.H.-S., and J.L.; software, J.M.G.-S., C.S., and J.L.; validation, F.J.H.-S., J.L., E.V., A.Q., J.R.-S., J.M.S., Á.A., B.Á., I.C., J.d.L., S.C., E.M., J.P., G.V., J.M.V., J.B. and M.S.-C.; formal analysis, J.M.G.-S., C.S., and J.L.; investigation, J.M.G.-S., F.J.H.-S., J.L., J.R.-S., J.M.S., Á.A., B.Á., I.C., J.d.L., S.C., E.M., J.P., G.V., J.M.V., J.B. and M.S.-C.; resources, all authors; data curation, J.M.G.-S., F.J.H.-S., J.L., J.R.-S., J.M.S., Á.A., B.Á., I.C., J.d.L., S.C., E.M., J.P., G.V., J.M.V., J.B. and M.S.-C.; writing-original draft preparation, J.M.G.-S.; writing-review and editing, J.M.G.-S., F.J.H.-S., J.L., E.V., M.Á.D.-P., and A.Q.; visualization, all authors; supervision, J.L., E.V., and A.Q.; project administration, J.M.G.-S.; funding acquisition, F.J.H.-S., J.L., and E.V. All authors have read and agreed to the published version of the manuscript.

Funding: This research was partially funded by Fundación Barcelona Zoo grant number PRIC 2017.

Acknowledgments: Thomas Sami Lahlafi, Aitor Rincón-García, Jesús Rodríguez-Osorio, Luis García-Cardenete, Jose M. Martín, Luis Llaneza, Ugo Melone, José Bueno, Enrique Ávila, Julio Blas, Ruth Muñiz, Miguel Garrido, Marcos Mallo and Sofía Capellán helped in some surveys. Francisco Chiclana and Manuel Tierno kindly identified some of the arthropods remains. The Haut Comissariat aux Eaux et Forêst et à la Lutte Contre la Désertification of Morocco allowed for these wildlife surveys. J. Rodríguez-Osorio is the author of the honey badger illustration of Figure 3.

Conflicts of Interest: The authors declare no conflict of interest.

\section{References}

1. Wilson, D.E.; Mittermeier, R.A. (Eds.) Handbook of the Mammals of the World. Vol 1. Carnivores; Lynx Editions: Barcelona, Spain, 2009.

2. Durant, S.M.; Wacher, T.; Bashir, S.; Woodroffe, P.; de Ornellas, P.; Ransom, C.; Newby, J.; Abáigar, T.; Abdelgadir, M.; El Alqamy, H.; et al. Fidding in biodiersity hotspots while deserts burn? Collapse of the Sahara's megafauna. Divers. Distrib. 2014, 20, 114-122. [CrossRef]

3. Brito, J.C.; Acosta, A.L.; Álvares, F.; Cuzin, F. Biogeography and conservation of taxa from remote regions: An application of ecological-niche based models and GIS to North-African Canids. Biol. Conserv. 2009, 142, 3020-3029. [CrossRef] 
4. Belbachir, F.; Pettorelli, N.; Wacher, T.; Belbachir-Bazi, A.; Durant, S.M. Monitoring Rarity: The Critically Endangered Saharan Cheetah as a Flagship Species for a Threatened Ecosystem. PLoS ONE 2015, 10, e0115136. [CrossRef]

5. Begg, C.; Begg, K.; Kingdon, J. Subfamily Mellivorinae. Ratel. In Mammals of Africa; Kingdon, J., Happold, D., Butynski, T., Hoffmann, M., Happold, M., Kalina, J., Eds.; Bloomsbury Natural History: London, UK, 2013; Volume V: Carnivores, Pangolins, Equids and Rhinoceroses; pp. 119-125.

6. Kruuk, H. Notes on food and foraging of the honey badger Mellivora capensis in the Kalahari Gemsbok National Park. Koedoe 1983, 26, 153-157. [CrossRef]

7. Begg, C.M.; Begg, K.S.; Du Toit, J.T.; Mills, M.G.L. Sexual and seasonal variation in the diet and foraging behaviour of a sexually dimorphic carnivore, the honey badger (Mellivora capensis). J. Zool. 2003, 260, 301-316. [CrossRef]

8. Valverde, J.A. Aves del Sahara Español (estudio ecológico del desierto); Consejo Superior de Investigaciones Científicas, Instituto de Estudios africanos: Madrid, Spain, 1957.

9. Dragesco-Joffé, A. La vie sauvage au Sahara; Delachaux et Niestlé: Paris, France, 1993.

10. Vale, C.G.; Campos, J.C.; Silva, T.L.; Goncalves, D.V.; Sow, A.S.; Martinez-Freiria; Zbyszek Boratynski1, F.Z.; Brito, J.C. Biogeography and conservation of mammals from the West Sahara-Sahel: An application of ecological niche-based models and GIS. Hystrix 2016, 27. [CrossRef]

11. Aulegnier, S.; Cuzin, F.; Thévenot, M. Mammifères sauvages au Maroc. Peuplement, répartition, ecologie; Société Française pour l'Etude et la Protection des Mammifères: Paris, France, 2017.

12. Hardin, G. The Competitive Exclusion Principle. Science 1960, 131, 1292-1297. [CrossRef]

13. Coyne, J.A.; Orr, H.A. Speciation; Oxford University Press: Oxford, UK, 2004.

14. Jdeidi, T.; Masseti, M.; Nader, I.; de Smet, K.; Cuzin, F. Mellivora capensis. The IUCN Red List of Threatened Species 2010. e.T41629A10522349. Available online: https://www.iucnredlist.org/species/41629/45210107 (accessed on 4 November 2019).

15. Kottek, M.; Grieser, J.; Beck, C.; Rudolf, B.; Rubel, F. World map of the Köppen-Geiger climate classification updated. Meteorol. Z. 2006, 15, 259-263. [CrossRef]

16. Barea-Azcón, J.M.; Virgós, E.; Ballesteros-Duperón, E.; Moleón, M.; Chirosa, M. Surveying carnivores at large spatial scales: A comparison of four broad-applied methods. Biodivers. Conserv. 2007, 16, 1213-1230. [CrossRef]

17. Robert, A.L.; MacKay, P.; William, J.Z.; Ray, J.C. Noninvasive survey methods for carnivores; Osiland Press: Washington, DC, USA; Covelo, CA, USA; London, UK, 2008.

18. O'Connell, A.F.; Nichols, J.D.; Karanth, K.U. Camera Traps in Animal Ecology: Methods and Analyses; Springer: Tokyo, Japan; Dordrecht, The Netherlands; Heildelberg, Germany; London, UK; New York, NY, USA, 2011.

19. Goldenberger, D.; Perschil, I.; Ritzler, M.; Altwegg, M. A simple "universal" DNA extraction procedure using SDS and proteinase $\mathrm{K}$ is compatible with direct PCR amplification. Genome Res. 1995, 4, 368-370. [CrossRef]

20. Kohn, M.; Knauer, F.; Stoffella, A.; Schröder, W.; Pääbo, S. Conservation genetics of the European brown bear-a study using excremental PCR of nuclear and mitochondrial sequences. Mol. Ecol. 1995, 4, 95-103. [CrossRef]

21. Leonard, J.A.; Wayne, R.K.; Cooper, A. Population genetics of Ice Age brown bears. Proc. Natl. Acad. Sci. USA 2000, 97, 1651-1654. [CrossRef]

22. Losey, R.J.; Bazaliiskii, V.I.; Garvie-Lok, S.; Germonpré, M.; Leonard, J.A.; Allen, A.L.; Katzenberg, M.A.; Sablin, M.V. Canids as persons: Early Neolithic dof and wolf burials, Cis-Baikal, Siberia. J. Anthropol. Archaeol. 2011, 30, 174-189. [CrossRef]

23. Meyer, M.; Kircher, M. Illumina sequencing library preparation for highly multiplexed target capture and sequencing. Cold. Spring. Harb. Protoc. 2010, 5, pdb-prot5448. [CrossRef]

24. Altschul, S.F.; Gish, W.; Miller, W.; Myers, E.W.; Lipman, D.J. Basic local alignment search tool. J. Mol. Biol. 1990, 215, 403-410. [CrossRef]

25. Kearse, M.; Moir, R.; Wilson, A.; Stones-Havas, S.; Cheung, M.; Sturrock, S.; Buxton, S.; Cooper, A.; Markowitz, S.; Duran, C.; et al. Geneious Basic: An integrated and extendable desktop software platform for the organization and analysis of sequence data. Bioinformatics 2012, 28, 1647-1649. [CrossRef]

26. Putman, R.J. Facts from faeces. Mammal Rev. 1984, 14, 79-97. [CrossRef] 
27. Barea-Azcón, J.M.; Ballesteros-Duperón, E.; Gil-Sánchez, J.M.; Virgós, E. Badger Meles meles feeding ecology in dry Mediterranean environments of the southwest edge of its distribution range. Acta Theriol. 2010, 55, 45-52. [CrossRef]

28. Buckland, S.T.; Anderson, D.R.; Burnham, K.P.; Laake, J.L.; Borchers, D.L.; Thomas, L. Advanced Distance Sampling: Estimating Abundance of Biological Populations; Oxford University Press: Oxford, UK, 2004.

29. Bartlett, R. Spiny-tailed Lizards: Uromastyx and Xenagama; Barron's Educational Series, Inc.: Hauppauge, NY, USA, 2003.

30. Thomas, L.; Buckland, S.T.; Rexstad, E.A.; Laake, J.L.; Strindberg, S.; Hedley, S.L.; Bishop, J.R.; Marques, T.A.; Burnham, K.P. Distance software: Design and analysis of distance sampling surveys for estimating population size. J. App. Ecol. 2010, 47, 5-14. [CrossRef]

31. Ferreras, P.; Díaz-Ruiz, F.; Monterroso, P. Improving mesocarnivore detectability with lures in camera-trapping studies. Wildl. Res. 2018, 45, 505-517. [CrossRef]

32. Monterroso, P.; Alves, P.C.; Ferreras, P. Catch me if you can: Diel activity patterns of mammalian prey and predators. Ethology 2013, 119, 1044-1056. [CrossRef]

33. Ridout, M.S.; Linkie, M. Estimating overlap of daily activity patterns from camera trap data. J. Agric. Biol. Environ. Stat. 2009, 14, 322-337. [CrossRef]

34. R Core Team. R: A Language and Environment for Statistical Computing. R Foundation for Statistical Computing. 2018. Available online: http://www.R-project.org/ (accessed on 18 January 2020).

35. Martínez del Mármol, G.; Harris, D.J.; Geniez, P.; de Pous, P.; Salvi, D. Amphibians and Reptiles of Morocco; Edition Chimaira: Frankfurt, Germany, 2019.

36. Roper, T. The European badger Meles meles: Food specialist or generalist? J. Zool. 2009, 234, 437-452. [CrossRef]

37. Stephens, D.W.; Krebs, J.R. Foraging Theory; Princeton University Press: Princeton, NJ, USA, 1986.

38. Schleich, H.H.; Kästel, W.; Kahisch, K. Amphibians and Reptiles of North Africa; Koeltz Sci. Books: Bonn, Germany, 1996.

39. Kruuk, H. The Social Badger. Ecology and Behaviour of A Group-Living Carnivore (Meles meles); Oxford University Press: Oxford, UK, 1989.

40. Fedriani, J.M.; Ferreras, P.; Delibes, M. Dietary response of the Eurasian badger, Meles meles, to a decline of its main prey in the Doñana National Park. J. Zool. 1998, 245, 214-218.

41. Tamar, K.; Metallinou, M.; Wilms, T.; Schmitz, A.; Crochet, P.; Geniez, P.; Carranza, S. Evolutionary history of spiny-tailed lizards (Lizardae: Uromastyx) from the Saharo-Arabian region. Zool. Scr. 2018, 47, 159-173. [CrossRef]

42. Cherkaoui, S.I.; Bouajaja, A. Recent records of the elusive Ratel Mellivora capensis (Schreber, 1776) in Morocco and case of human persecution. IUCN/SCC Small Carnivore Conservation Journal 2017, 55, 64-68.

43. Donadio, E.; Buskirk, S.W. Diet, morphology, and interspecific killing in Carnivora. Am. Naturalist 2006, 167, 524-536. [CrossRef]

44. Vanak, A.T.; Fortin, D.; Thaker, M.; Ogden, M.; Owen, C.; Greatwood, S.; Slotow, R. Moving to stay in place: Behavioral mechanisms for coexistence of African large carnivores. EcolM MJKgy 2013, 94, 2619-2631. [CrossRef]

45. Lovari, S.; Pokheral, C.P.; Jnawali, S.R.; Fusani, L.; Ferretti, F. Coexistence of the tiger and the common leopard in a prey-rich area: The role of prey partitioning. J. Zool. 2015, 295, 122-131. [CrossRef]

(C) 2020 by the authors. Licensee MDPI, Basel, Switzerland. This article is an open access article distributed under the terms and conditions of the Creative Commons Attribution (CC BY) license (http://creativecommons.org/licenses/by/4.0/). 